\title{
FOOTPRINT GLANDS IN AMBLYOPONE AUSTRALIS (FORMICIDAE, PONERINAE)
}

\author{
By Bert Hölldobler* and Jacqueline M. Palmer \\ Department of Organismic and Evolutionary Biology, \\ Museum of Comparative Zoology, Harvard University, \\ Cambridge, MA 02138, USA
}

\section{INTRODUCTION}

Social communication in ants is based primarily on chemical signals (for recent reviews see Morgan 1984; Hölldobler and Wilson, 1990). Semiochemicals (or pheromones) are produced in exocrine glands, and when discharged these substances elicit in nestmates specific behavioral patterns, such as alarm reactions and recruitment responses. In recent years the study of chemical communication has received a new impetus by the discovery of many hitherto unknown exocrine glands (see Hölldobler and Engel, 1978, 1982; Jessen et al. 1979; Hölldobler 1982; Billen 1986). In the present paper we report the discovery of special exocrine glands in the distal tarsomere of the hindlegs of Amblyopone australis workers. The morphology of the glands and behavioral observations suggest that foragers of Amblyopone mark their trails by setting "footprints" with secretions from these tarsal glands.

\section{Materials AND Methods}

Several colonies of Amblyopone australis were collected near Canberra (Australia) and workers were fixed in Carnoy's fixative and stored in $80 \%$ ethanol. After clearing in toluene, the legs of workers were embedded in an ultra-low viscosity epoxy medium (VCD/HXSA) as described by Mascorro et al. (1976) and Oliveira et al. (1983). Blocks were serially sectioned at $2 \mu \mathrm{m}$ using glass knives and a model MT2-C ultramicrotome (Research Manufacturing Company, Tucson, Arizona). Sections were attached to albumized

*Requests for reprints should be sent to Bert Hölldobler; present address; Zoological Institute, University of Würzburg, 8700 Würzburg, Federal Republic of Germany. Manuscript received by the editor May 21, 1989. 


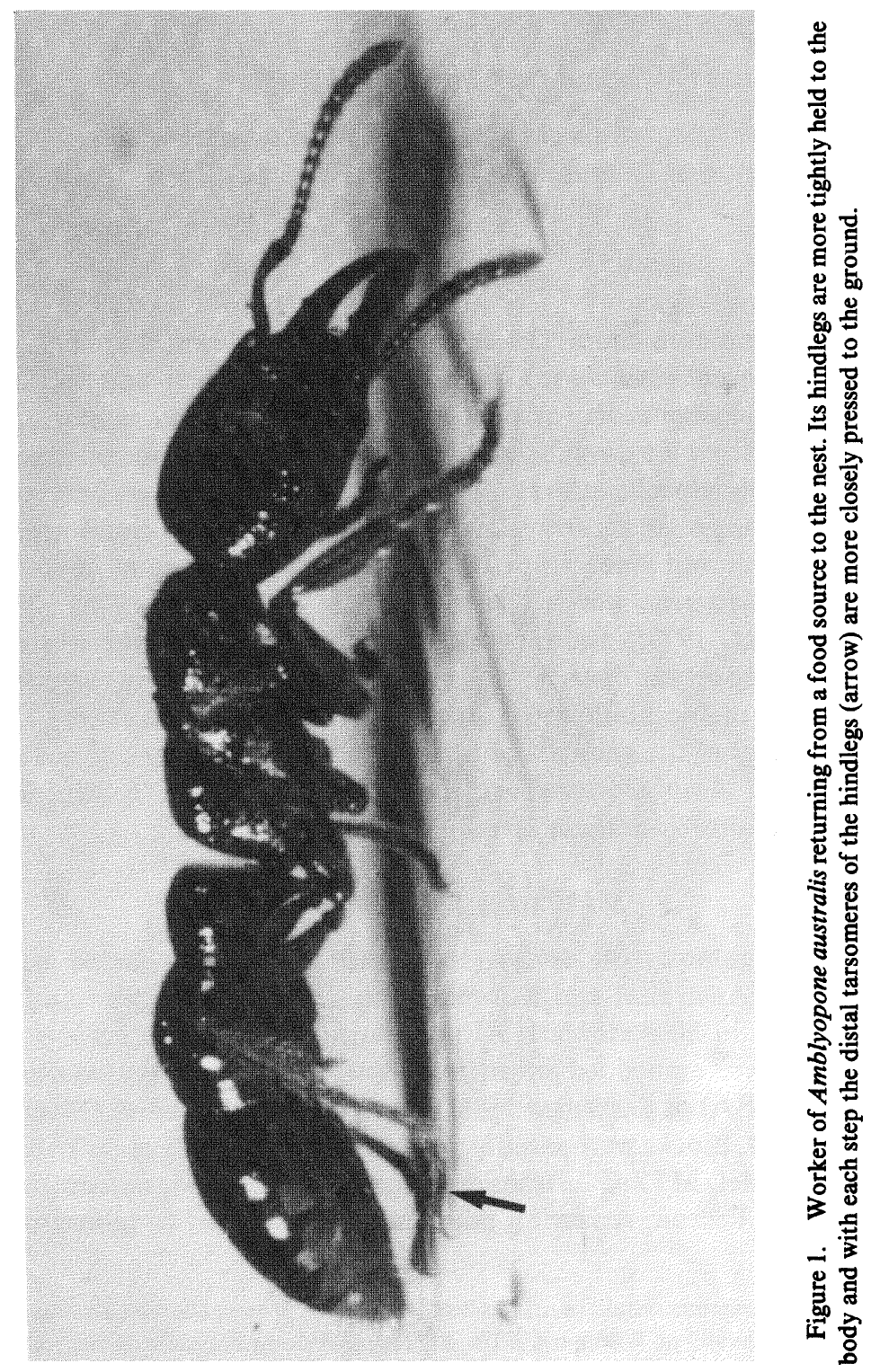




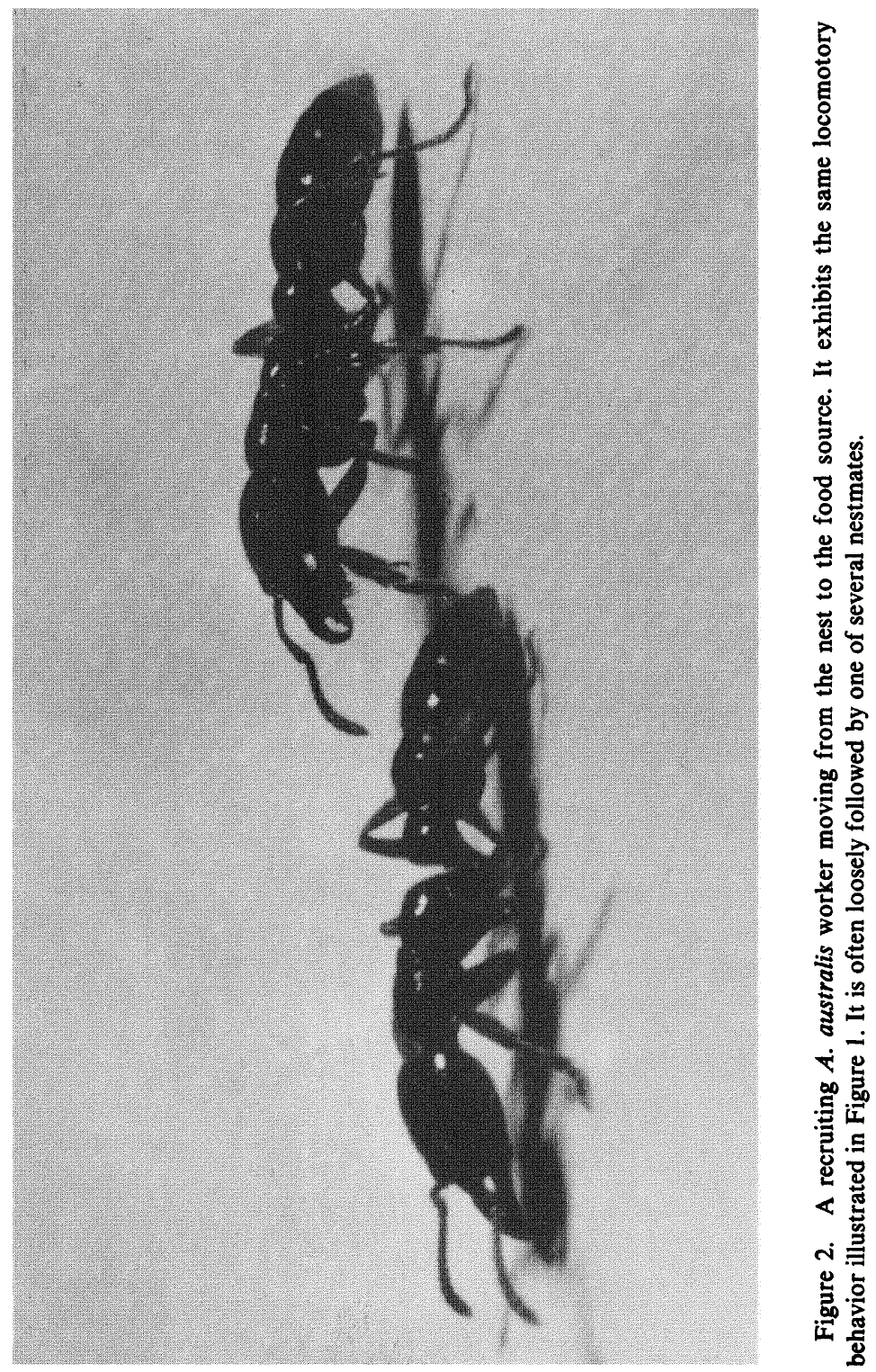



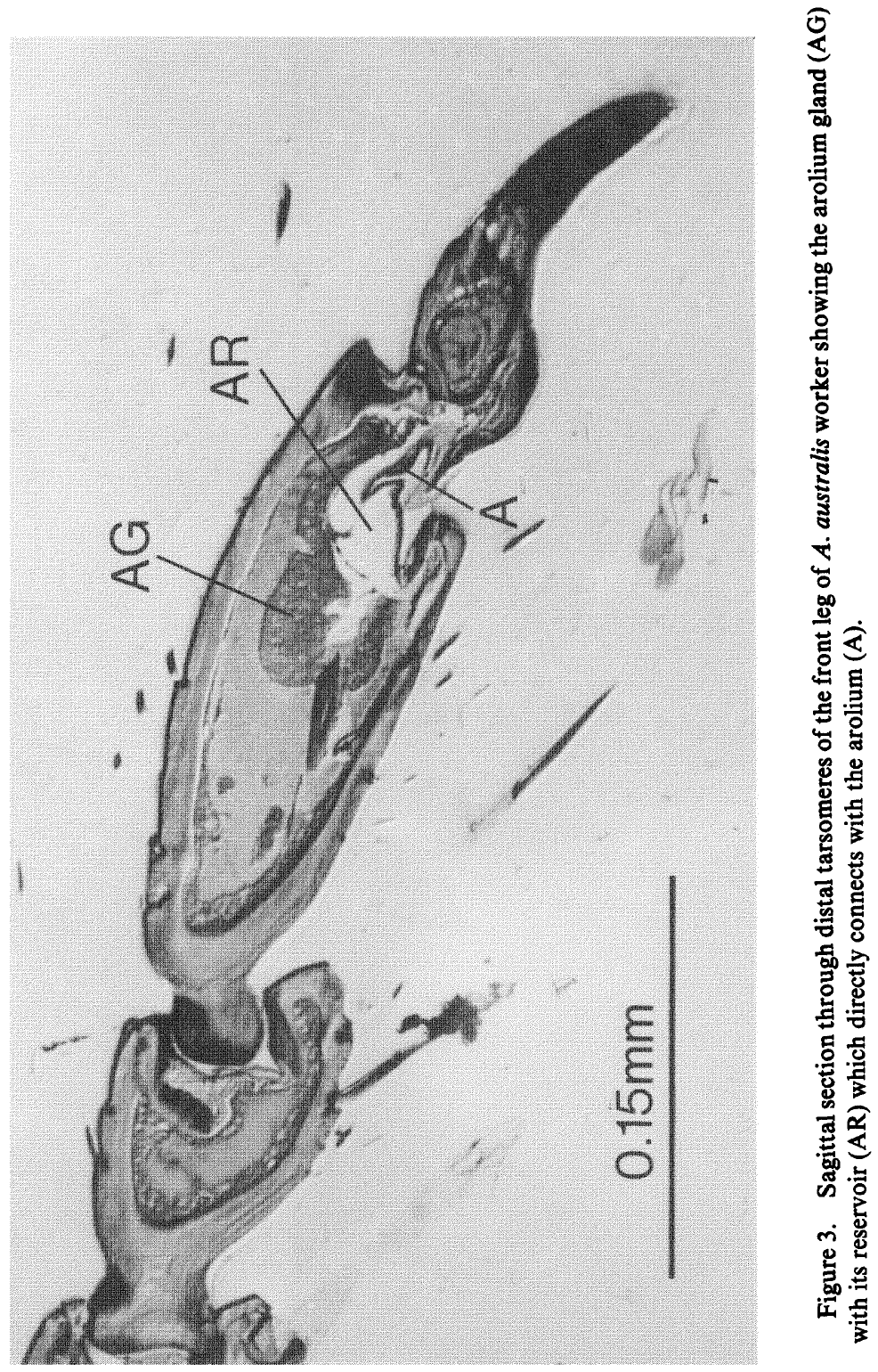


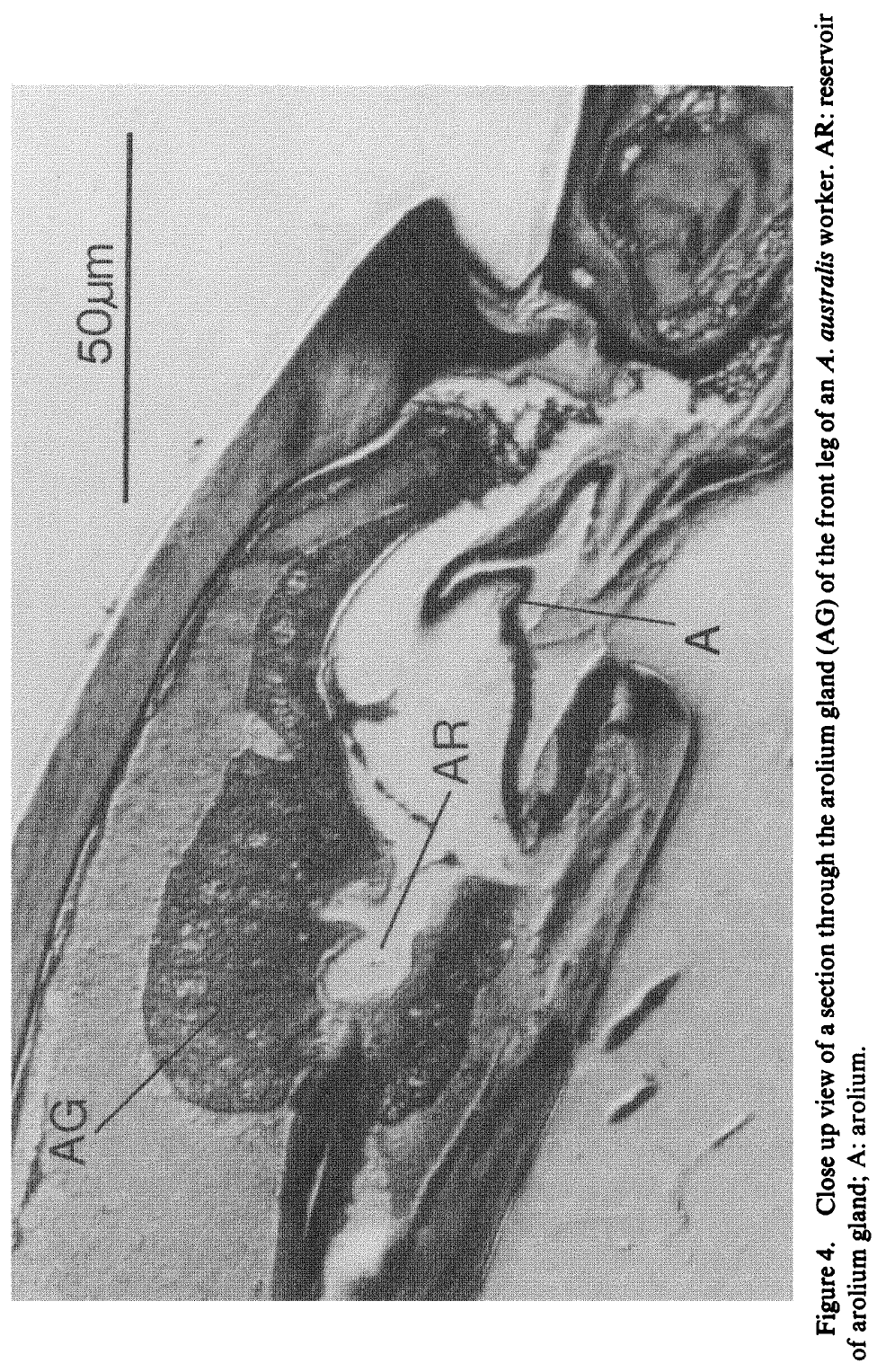



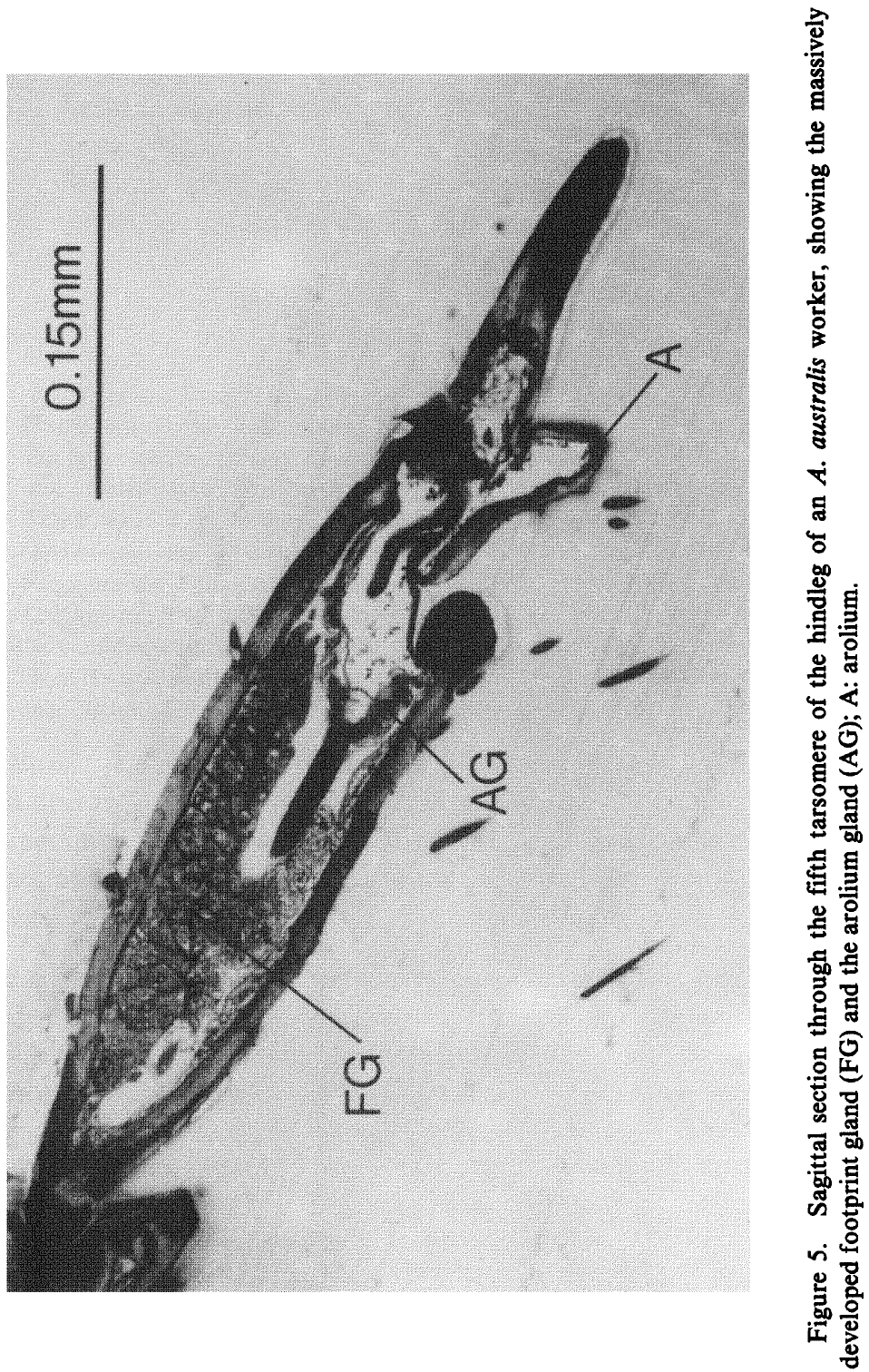


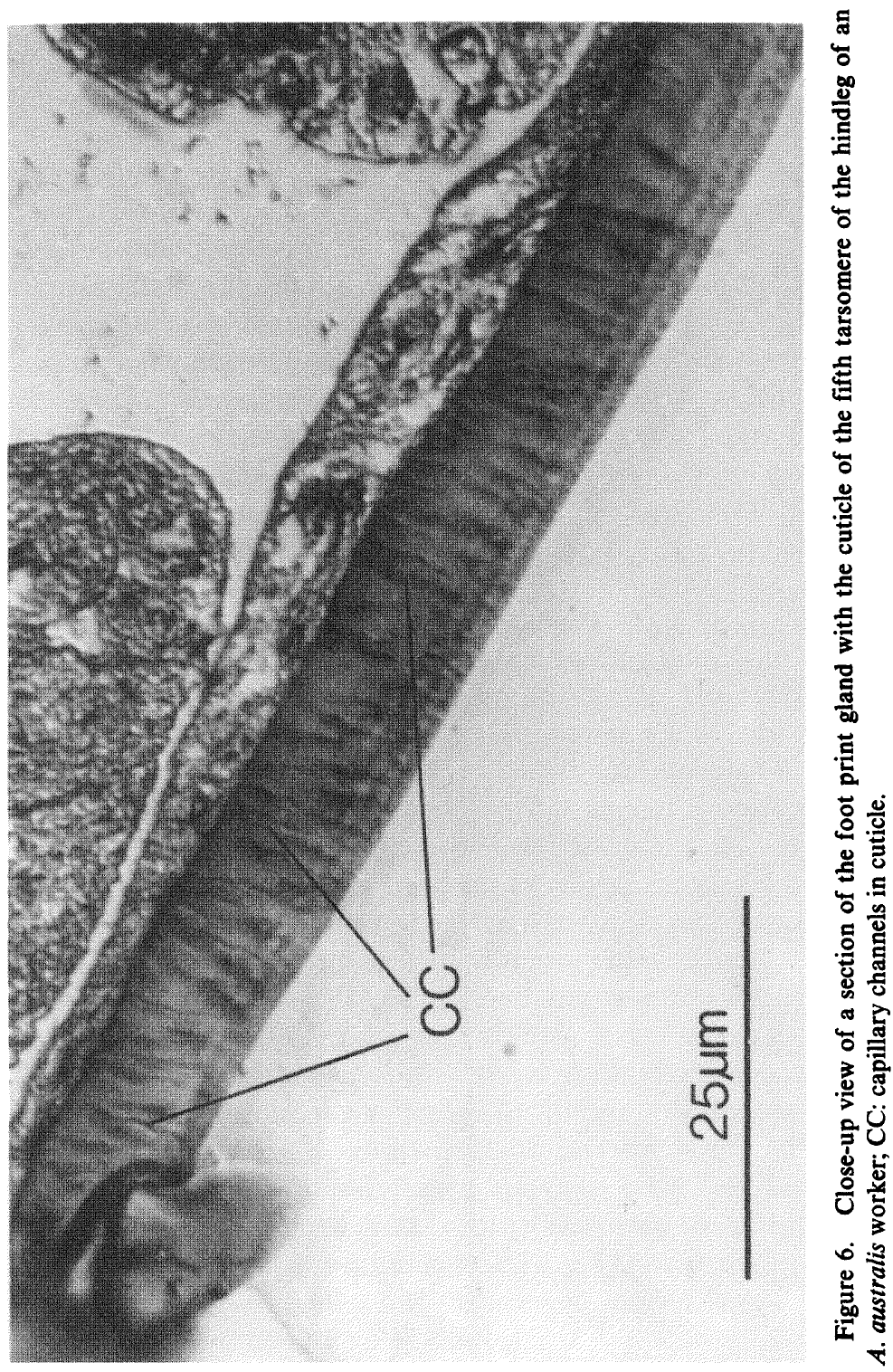


glass slides and plastic was removed prior to staining with toluidine blue/basic fuchsin following Burns and Bretschneider (1981) with slight modifications.

\section{RESULTS}

An ongoing experimental analysis of the communication system of Amblyopone australis and A. longidens has revealed that these phylogenetically primitive species employ a rather complex combination of vibrational and chemical signals during recruitment to food sources (Hölldobler and Markl, unpublished). Recruiting ants conduct inside the nest a vigorous body shaking display that propagates general alert and stimulation among nestmates and chemical signals deposited along the trail of the recruiting ant give directional information about the location of the newly discovered food source. Behavioral tests clearly demonstrate that the recruiting forager as well as the recruits move along chemically marked trails. The trail following is not very precise, but in laboratory experiments a significant majority of recruits departed the nest in the direction from which the recruiting ant had returned.

Hölldobler and Markl (unpublished) also observed that the recruiting ant, when moving from the food source to the nest, changed its locomotory behavior in a subtle, but nevertheless noticeable way. It moved more slowly, holding its hind legs more tightly to the body and with each step pressed the distal tarsomeres of the hind legs more closely to the ground (Fig. 1). The ant exhibited the same behavior when leaving the nest again to return to the food source. In the latter situation it was often accompanied by a group of one or several nestmates (Fig. 2). These and other observations as well as pilot tests with extracts from hind legs suggest that Amblyopone workers mark trails with footprint secretions. In the following we present our histological investigations of exocrine glands in the legs of workers of $A$. australis.

We found two types of tarsal glands in Amblyopone workers. One type is located between the fifth tarsal segment and the pretarsal claws at the arolium (Fig. 3). The gland consists of a reservoir sac lined with an epithelium of secretory cells. The reservoir connects directly with the lumen of the arolium (Fig. 4). and most likely this gland produces secretions for adhesion. The arolium is believed to serve as an adhesive organ to surfaces too hard or too smooth for 
the claws to grasp (Snodgrass, 1956). This "arolium gland" has been found in all 6 legs of Amblyopone workers and resembles closely the tarsal glands Billen (1986) described in the wasp Polistes annularis.

The second type of tarsal gland found in A. australis, consists of a massive glandular cell cluster which is especially well developed in the elongated fifth tarsal segment of the hind legs (Fig. 5). This structure appears to be associated with a dense pattern of pore capillaries penetrating the cuticle of the ventral fifth tarsomere (Fig. 6). Such pore capillaries are absent in the dorsal part of the cuticle. The gland can also be found in the fifth tarsomere of the middle leg, where it is, however, poorly developed. It appears to be absent altogether in the front leg (Fig. 3).

\section{Discussion}

A surprisingly large number of exocrine structures have been identified as sources for trail pheromones in ants (see reviews in Hölldobler 1984; Attygalle and Morgan 1986; Hölldobler and Wilson, 1990). In almost all species studied, trail pheromones originate from organs located in the gaster of the ants. The myrmicine genus Crematogaster is an exception, however, as the workers lay trails with secretions from a special tibial gland (Fletcher and Brand, 1968; Leuthold, 1968). For more detailed morphological descriptions of this gland see Pasteels et al. (1970) and Billen (1984).

In the present paper we report the presence of tarsal glands in the hind legs of Amblyopone australis which, considering the complementary behavioral observations (Hölldobler and Markl, unpublished), are suspected as a source for trail pheromones. It is possible that footprint marking is a more general phenomenon in ants than previously thought. In fact, several ant species are known to employ chemical "sign posts" for home range marking and orientation. In addition some species have recently been demonstrated to deposit colony specific and even individual specific chemical orientation cues (see Jessen and Maschwitz, 1986; for review see Hölldobler and Wilson, 1990). In most of these cases we do not yet know the exact anatomical source of these specific marking pheromones. Our discovery of tarsal "footprint glands" suggests new possibilities for the investigation of chemical marking signals in ants. 


\section{ACKNOWLEDGMENTS}

This study was supported by a grant from the National Science Foundation (USA) no. BNS 8521575.

\section{REFERENCES}

Billen, J. 1984. Morphology of the tibial gland in the ant Crematogaster scutellaris. Naturwissenschaften 71: 324-325.

1986. Etude morphologique des glandes tarsales chez la guêpe Polistes annularis (L.) (Vespidae, Polistinae). Actes Coll. Insectes Soc. 3: 51-60.

1987. Morphology and ultrastructure of the exocrine glands in social Hymenoptera. In Eder, J. and Rembold, H. eds. Chemistry and Biology of Social Insects. pp. 81-84, Verlag J. Peperny, Munich.

Burns, M. S. ANd A. Bretschneider. 1981. Thin is in. American Society of Clinical Pathologists, Educational Products Division, Chicago, pp. 19-20.

Fletcher, D. J. C. AND J. M. Brand. 1968. Source of the trail pheromone and method of trail laying in the ant Crematogaster peringueyi. J. Insect Physiol. 14: 783-788.

HólldDobler, B. 1982. Chemical communication in ants: New exocrine glands and their behavioral function. In Breed, M. D., Michener, C. D., Evans, H. E. eds. The Biology of Social Insects, pp. 312-317, Westview Press, Boulder.

AND H. Engel. 1978. Tergal and sternal glands in ants. Psyche 85: 285-330.

AND

1982. Tergal and sternal glands in male ants. Psyche 89:

113-132

ANd E. O. Wilson. 1990. The Ants. Harvard University Press, in press.

Jessen, K., U. Maschwitz, M. Hahn. 1979. Neue Abdominaldrüsen bei Ameisen. I. Ponerini (Formicidae: Ponerinae). Zoomorphologie 94: 49-66.

AND U. MASCHWITZ. 1986. Orientation and recruitment behavior in the ponerine ant Pachycondyla tesserinoda (Emery): laying of individualspecific trails during tandem running. Behavioral Ecology and Sociobiology 19: 151-155.

LeUthold, R. H. 1968. A tibial gland scent-trail and trail-laying behavior in the ant Crematogaster ashmeadi Mayr. Psyche 75: 233-248.

MASCORRo, J., M. W. LADD, R. D. YATES. 1976. Rapid infiltration of biological tissues utilizing n-hexenyl succinic anhydride (HSXA/vinyl cyclohexene dioxide (VCD)), an ultra-low viscosity embedding medium. 34th Annual Proceedings Electron Microscopy Society of America, p. 346.

Morgan, E. D. 1984. Chemical words and phrases in the language of pheromones for foraging and recruitment. In T. Lewis, ed. Insect Communication (Symposium of the Royal Entomological Society of London, no. 12) pp. 169-194, Academic Press, London.

Oliveira, L., A. Burns, T. Bisalputra, K. Yang. 1983. The use of an ultra-low viscosity medium (VCD/HXSA) in the rapid embedding of plant cells for electron microscopy, J. Microsc. 132: 195-202. 
Pasteels, J. M., R. M. Crewe, M. S. Blum. 1970. Etude histologique et examen au microscope electronique a balayage de la glande secretant la pheromone de piste chez deux Crematogaster nord-americains (Formicidae, Myrmicinae). C. R. Acad. Sc. Paris, 271D: 835-838.

Snodgrass, E. R. 1956. Anatomy of the Honey Bee. Comstock Publishing Associates, Cornell University Press, 334 pp. 

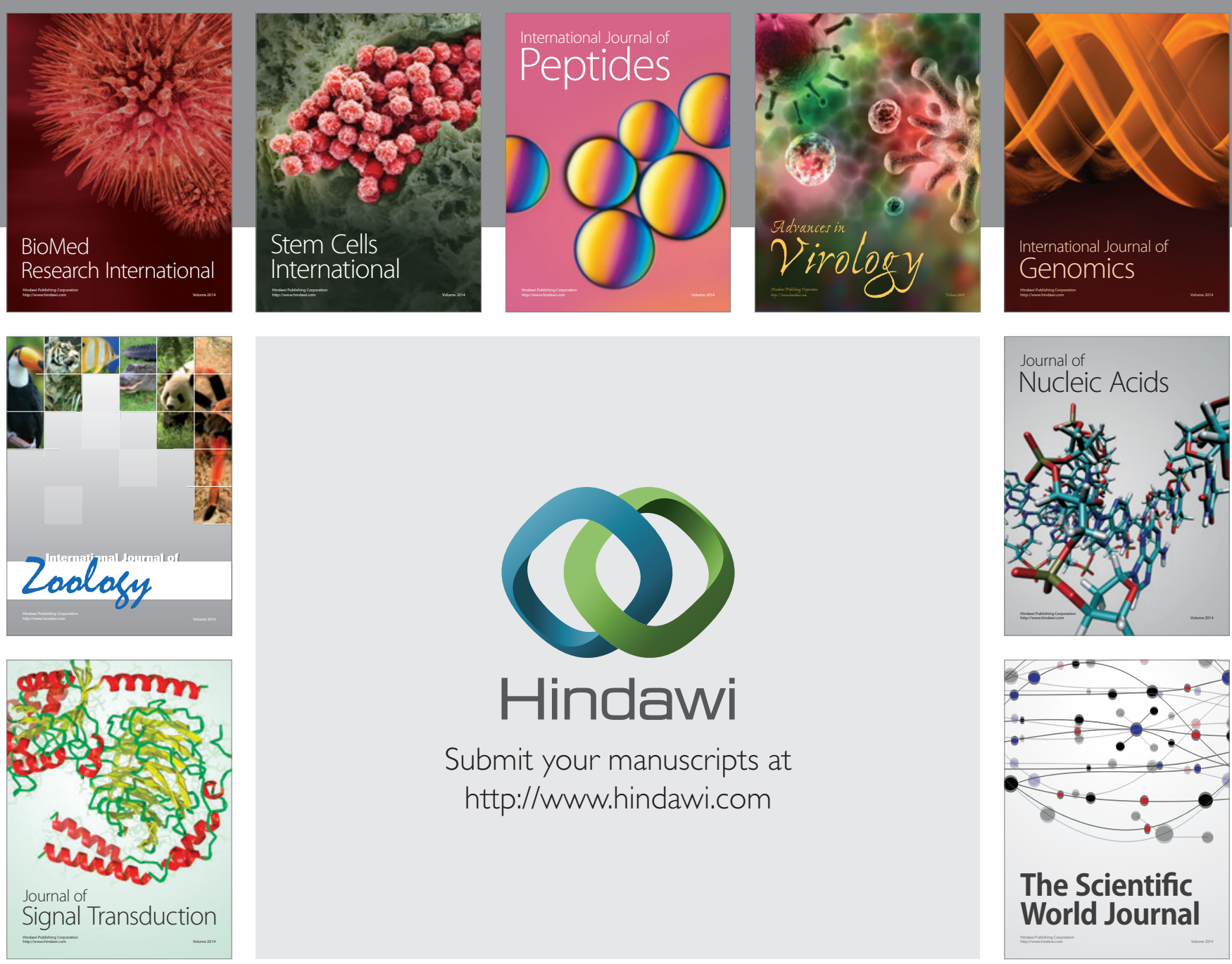

Submit your manuscripts at

http://www.hindawi.com
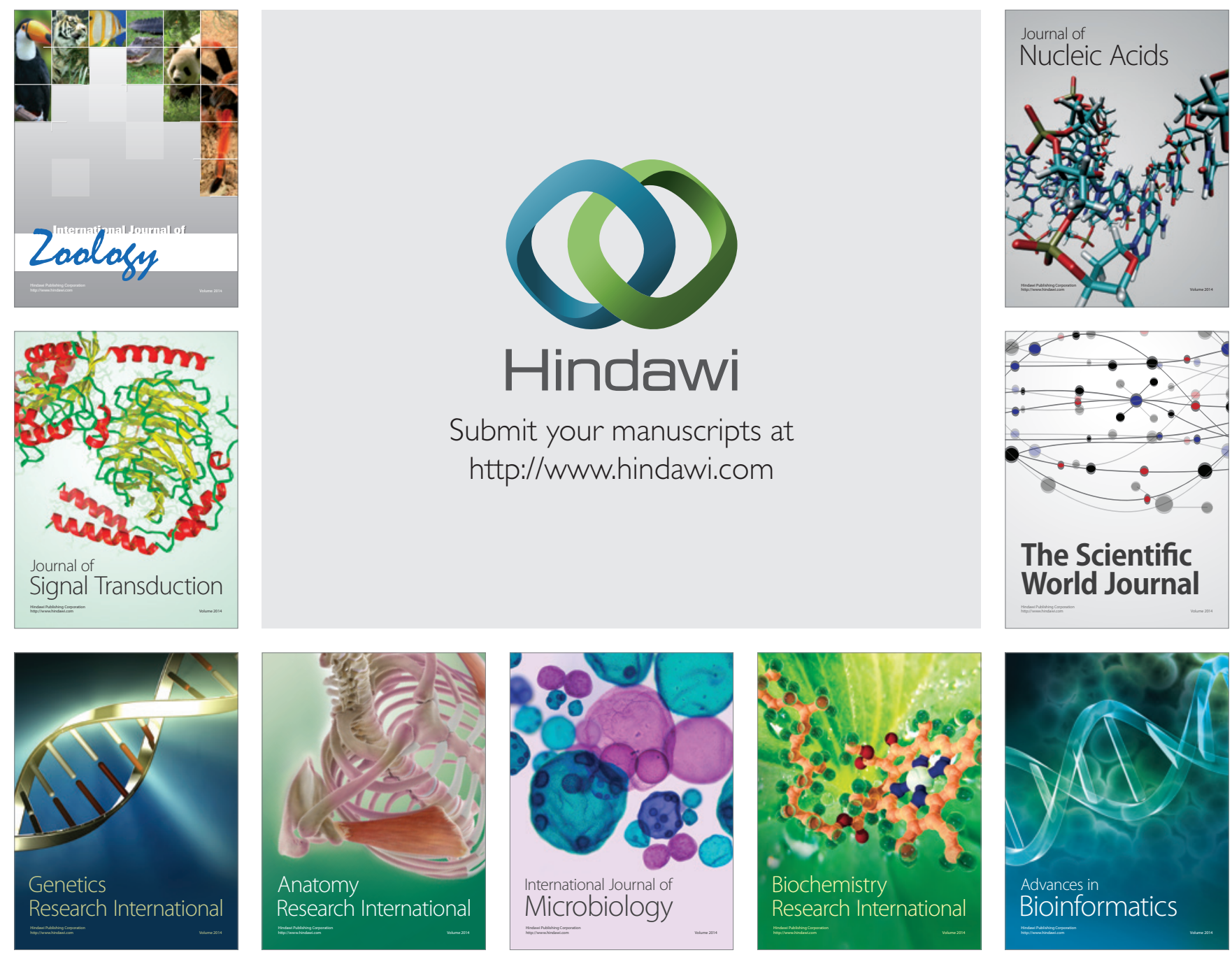

The Scientific World Journal
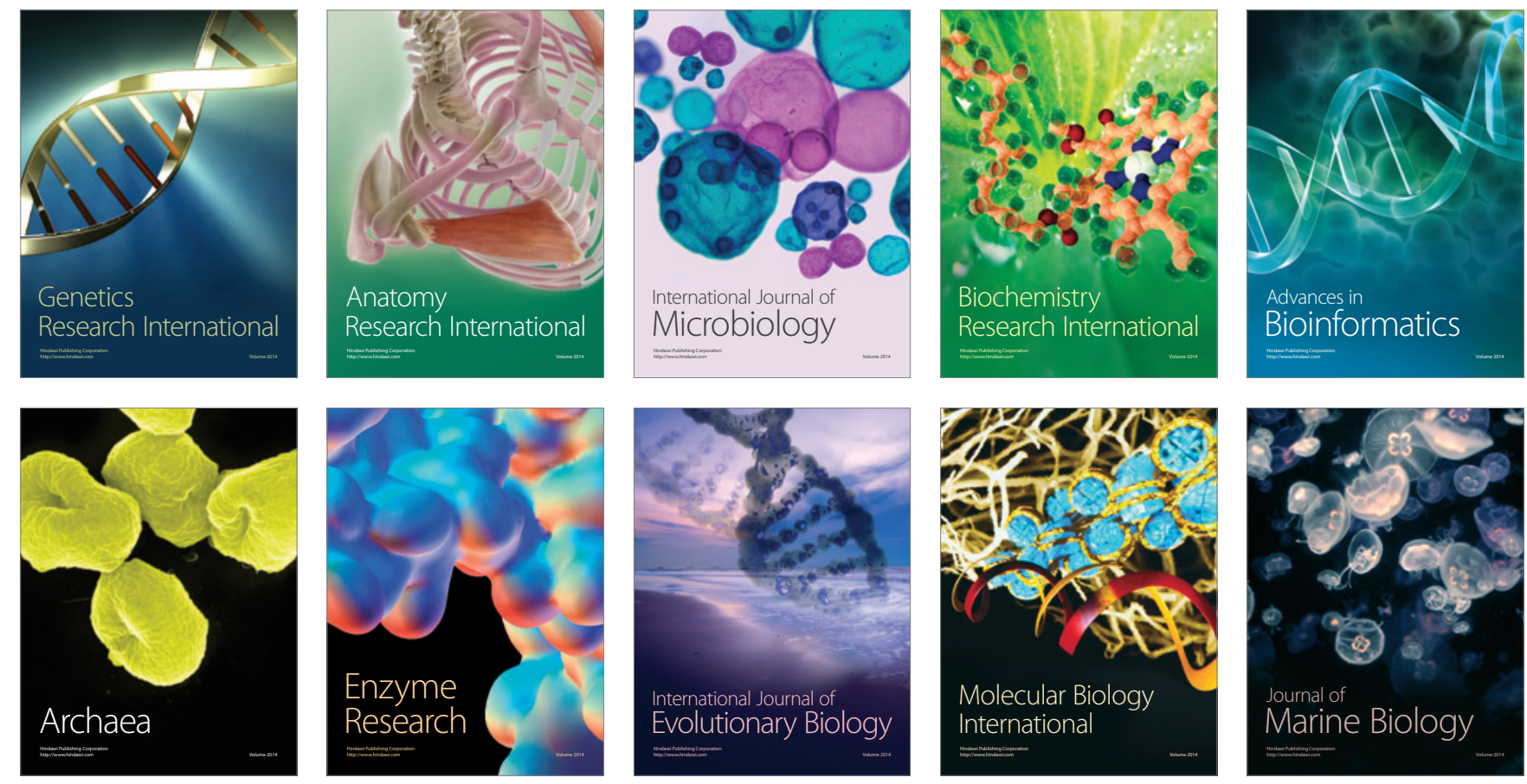